$\mathrm{A} \mathrm{J}_{\mathrm{sin}} \mathrm{H}$

Article history :

Received : 30.04.2015

Accepted : 30.05.2015
THEASIAN JOURNALOF HORTICULTURE

Volume 10 | Issue 1 | June, 2015 | 177-180

Visit us -www.researchjournal.co.in

\title{
Effect of integrated nutrient management on yield of sapota
}

Members of the Research Forum

Associated Authors:

${ }^{1}$ Krishi Vigyan Kendra, Navsari

Agricultural Univeristy, NAVSARI (GUJARAT) INDIA
Author for correspondence : B.M. TANDEL

Krishi Vigyan Kendra, Navsari

Agricultural Univeristy, NAVSARI

(GUJARAT) INDIA

Email : hariombhupi@gmail.com

\section{B.M. TANDEL, PRABHU NAYAKA ${ }^{1}$, K.A. SHAH ${ }^{1}$ AND C.K. TIMBADIA ${ }^{1}$}

ABSTRACT : Constraints in sapota production and their elucidation at farming communities were studied with the involvement of farmer's. In this regard demonstrations on sapota were conducted in 58 villages of Jallpore, Navsari and Gandevi taluks of Navsari in an area of about 529 ha with involvement of 2645 farmer's. These areas were grouped in to 10 clusters. Demonstrations were focused on the use bio-fertilizer along with organic manures in with recommended dose of fertilizer management practices. From the study found that over the years high yield of fruit was obtained through use of organic manure vermi compost along with bio-fertilizer than traditional method of fertilizer management. Among the ten clusters studied Manekpor cluster recorded with highest B: C ratio (6.18) and Gadat cluster recorded extension gap (2.8) and technology index (18.5) as compared to other clusters.

KEY WORDS : Sapota, INM, Bio-fertilizer, Bio-pesticide

HOW TO CITE THIS ARTICLE : Tandel, B.M., Nayaka, Prabhu, Shah, K.A. and Timbadia, C.K. (2015). Effect of integrated nutrient management on yield of sapota. Asian J. Hort., 10(1) : 177-180. 